Penerbit:

Program Studi Magister Ilmu Kesehatan Masyarakat, Program Pascasarjana, Universitas Sam Ratulangi

Indonesian Journal of Public Health and Community Medicine is indexed by Google Scholar and licensed under a Creative Commons Attribution 4.0 International License.

\title{
Apakah Tingkat Pendidikan dan Frekuensi Senam Aerobik berhubungan dengan Status Gizi?
}

\author{
Bella Cloudia Chairudin ${ }^{1 *}$, Aaltje Ellen Manampiring ${ }^{2}$, Jeini Ester Nelwan ${ }^{3}$ \\ ${ }^{1}$ Program Studi Ilmu Kesehatan Masyarakat, Program Pascasarjana Universitas \\ Sam Ratulangi \\ ${ }^{2}$ Fakultas Kedokteran Universitas Sam Ratulangi \\ ${ }^{3}$ Fakultas Kesehatan Masyarakat Universitas Sam Ratulangi \\ *E-mail: bellacloudia07@gmail.com
}

\begin{abstract}
Abstrak
Latar Belakang: Status gizi juga merupakan keadaan fisik seseorang yang ditentukan dengan salah satu atau kombinasi ukuran-ukuran gizi seperti indeks massa tubuh. Status gizi secara tidak langsung dipengaruhi oleh frekuensi olahraga yang bersifat aerobik/ anaerobik dan tingkat pendidikan. Tujuan penelitian ini yaitu untuk menganalisis hubungan antara tingkat pendidikan dan frekuensi senam aerobik dengan status gizi pada anggota Balai Kesehatan Olahraga Dinas Kesehatan Provinsi Sulawesi Utara. Metode Penelitian: Penelitian ini merupakan penelitian kuantitatif dengan menggunakan desain penelitian studi potong lintang. Penelitian ini dilaksanakan pada bulan Juni-Juli 2020 di Balai Kesehatan Olahraga Masyarakat Dinas Kesehatan Provinsi Sulawesi Utara. Penelitian ini menggunakan 30 responden. Variabel penelitian ini yaitu status gizi, tingkat pendidikan dan frekuensi senam aerobik. Penelitian ini menggunakan data sekunder dengan cara pengambilan sampel dari data anggota yang ada di Balai Kesehatan Olahraga Masyarakat. Data diuji menggunakan uji Fisher's Exact. Hasil Penelitian: Hasil penelitian menunjukkan bahwa sebanyak 27 responden memiliki IMT <18,522,9, 24 responden memiliki pendidikan S1 / D3 dan 15 responden masuk pada kelompok frekuensi senam aerobik sebanyak 37-50 kali. Hasil penelitian ini menunjukkan tidak terdapat hubungan antara tingkat pendidikan dengan status gizi $(p=0,501)$ dan tidak terdapat hubungan antara frekuensi senam aerobik dengan status gizi $(p=1,000)$. Kesimpulan: Kesimpulan penelitian ini yaitu tingkat pendidikan dan frekuensi senam aerobik tidak berhubungan dengan status gizi pada anggota Balai Kesehatan Olahraga.
\end{abstract}

Kata Kunci: tingkat pendidikan; frekuensi senam aerobik; status gizi

\section{Abstract}

Background: Nutritional status is also a person's physical condition which is determined by one or a combination of nutritional measures such as body mass index. Nutritional status is indirectly influenced by the frequency of aerobic/ anaerobic exercise and the level of education. The purpose of this study was to analyze the correlation between education level and frequency of aerobic exercise with nutritional status of members of the Sports Health Center of Health Office 
North Sulawesi Province. Methode: This is a correlational research with a cross-sectional approach. This research was conducted in June-July 2020 at the Community Sports Health Center of Health Office North Sulawesi Province. This study used 30 respondents. The variables of this study were nutritional status, level of education and frequency of aerobic exercise. This study uses secondary data from existing member at the Community Sports Health Center. Data were tested using Fisher's Exact test. Result: The results showed that 27 respondents had a BMI <18.5-22.9, 24 respondents had S1/ D3 degree and 15 respondents were aerobic exercise frequency as much as 37-50 times. The results of this study indicated that there was no correlation between education level with nutritional status $(p=0.501)$ and there was no correlation between the frequency of aerobic exercise with nutritional status $(p=1,000)$. Conclusion: The conclusion of this study is that the level of education and the frequency of aerobic exercise are not correlation with the nutritional status of the members of the Sports Health Center.

Keywords: education level; frequency of aerobic exercise; nutritional status

\section{PENDAHULUAN}

Status gizi adalah faktor yang berada pada manusia dan bersifat individu. Status gizi dapat dipengaruhi secara langsung dari jumlah makanan, jenis asupan yang ada pada makanan dan kondisi tubuh. Status gizi juga merupakan keadaan fisik setiap individu yang ditentukan dari ukuran-ukuran gizi salah satunya yaitu indeks massa tubuh (IMT) (Supariasa dan Hardinsyah, 2016). IMT merupakan salah satu indeks anthropometri untuk memantau status gizi orang dewasa, lebih khusus yang berhubungan dengan kekurangan dan kelebihan berat badan (Supariasa, 2013). IMT diartikan sebagai berat badan seseorang dalam kilogram dibagi dengan tinggi badan dalam meter $\left(\mathrm{kg} / \mathrm{m}^{2}\right)$ (Irianto, 2017).

Berdasarkan laporan dari WHO (2017) bahwa lebih dari 1,9 miliar orang dewasa berumur 18 tahun ke atas mengalami kelebihan berat badan, dan lebih dari 650 juta orang mengalami obesitas. Sebagian besar penduduk di negara-negara yang memiliki masalah kesehatan kelebihan berat badan dan obesitas menjadi penyebab kematian paling banyak dibandingkan dengan masalah kekurangan berat badan. Indonesia merupakan negara berkembang yang memiliki masalah gizi ganda atau double burden. Sulawesi Utara sebagai salah satu provinsi yang memiliki prevalensi obesitas tertinggi yaitu sebesar 30,2\% (Kemenkes RI, 2018).

Faktor-faktor yang mempengaruhi status gizi antara lain usia, jenis kelamin, pola makan, aktivitas fisik dan pendidikan (Hidayati, 2017). Pendidikan dalam hal ini berhubungan dengan pengetahuan. Semakin tinggi pendidikan seseorang, status gizinya akan semakin baik, dikarenakan hal ini akan mempengaruhi pemilihan bahan makanan dan pemenuhan kebutuhan gizi. Hal ini sejalan dengan hasil penelitian dari Wati (2019) dan Harianti (2018) yang menunjukkan adanya hubungan antara tingkat pendidikan dengan status gizi.

Olahraga adalah salah suatu aktivitas fisik yang teratur dan terstruktur untuk meningkatkan ketahanan fisik sekaligus sebagai upaya memelihara kesehatan dan kebugaran. Olahraga dapat berupa latihan yang bersifat aerobik maupun anaerobik. Menurut Sorensens, senam aerobik merupakan salah satu jenis senam kebugaran atau kesehatan jasmani yang sangat lengkap karena mencakup beberapa latihan dan juga kegembiraan yang dapat mengekspresikan semua perasaan dengan cara tertawa, bergoyang, melompat, meregangkan badan, dan dikombinasikan dengan tarian rakyat, tarian tradisional, dan juga tarian kontemporer (Syafei 2017). Hasil penelitian sebelumnya dari Ria et al (2017) dan Kuswari et al (2015) bahwa terdapat hubungan 
antara frekuensi senam aerobik dengan IMT.

Dari hasil observasi dan wawancara pada salah satu intruktur senam aerobik di Balai Kesehatan Olahraga bahwa pada umumnya anggota senam aerobik di Balai Kesehatan Olahraga memiliki perubahan berat badan. Perubahan berat badan tersebut terjadi berbeda-beda pada setiap anggota. Setiap anggota memiliki frekuensi senam aerobik yang berbeda juga, dikarenakan aktifitas dan profesi yang berbeda-beda. Setiap anggota memiliki latar belakang pendidikan yang berbeda- beda. Anggota yang ada di Balai Kesehatan Olahraga sebagian besar termasuk dalam usia kelompok pemuda. Terjadinya perubahan berat badan tersebut menjadi salah satu motivasi bagi anggota yang ada di Balai Kesehatan Olahraga lebih semangat dan rutin mengikuti latihan senam aerobik. Berdasarkan latar belakang diatas maka tujuan penelitian ini ialah untuk menganalisis hubungan antara tingkat pendidikan dan frekuensi senam aerobik dengan status gizi anggota Balai Kesehatan Olahraga Dinas Kesehatan Provinsi Sulawesi Utara.

\section{METODE PENELITIAN}

Penelitian ini merupakan penelitian korelasional dengan pendekatan cross sectional study (studi potong lintang). Penelitian ini dilaksanakan pada bulan Juni-Juli 2020 di Balai Kesehatan Olahraga Masyarakat Dinas Kesehatan Provinsi Sulawesi Utara. Sampel dalam penelitian ini yaitu seluruh anggota senam aerobik yang tercatat pada bulan Januari-Maret 2020 dengan jumlah 30 anggota. Variabel terikat dalam penelitian ini yaitu status gizi dan variabel bebas dari penelitian ini yaitu tingkat pendidikan dan frekuensi senam aerobik. Penelitian ini menggunakan data sekunder. Penelitian ini menggunakan analisis data univariat dan bivariat dengan uji statistik Fisher's Exact.

\section{HASIL DAN PEMBAHASAN}

Dalam subbagian ini dijelaskan hasil analisis data penelitian secara univariat dan bivariat. Analisis univariat menjelaskan distribusi data berdasarkan karakteristik responden dan variabel penelitian seperti tinggi badan, berat badan, status gizi, tingkat pendidikan dan frekuensi senam aerobik. Hal ini terlihat pada Tabel 1.

Tabel 1. Distribusi responden berdasarkan karakteristik dan variabel penelitian

\begin{tabular}{cccc}
\hline Karakteristik responden & Kategori & N & $\mathbf{\%}$ \\
\hline Tinggi badan (cm) & $153-159$ & 12 & 40.0 \\
& $160-163$ & 8 & 26.7 \\
Berat badan (kg) & $164-166$ & 10 & 33.3 \\
& $50-53$ & 5 & 16.7 \\
Status gizi (IMT) & $54-57$ & 15 & 50.0 \\
& $58-70$ & 10 & 33.3 \\
Tingkat pendidikan & Normal (18,5-22,9) & 27 & 90.0 \\
& Tidak (<18,5 atau $>22,9)$ & 3 & 10.0 \\
Frekuensi senam aerobik & Tinggi (D3/ S1) & 24 & 80.0 \\
& Menengah (SMP/ SMA) & 6 & 20.0 \\
& Tinggi (27-50 kali) & 15 & 50.0 \\
& Rendah (23-36 kali) & 15 & 50.0 \\
\hline
\end{tabular}

Tabel 1 menunjukkan bahwa responden paling banyak terdistirbusi pada kategori tinggi badan (TB) 153-159 $\mathrm{cm}$ sebanyak 12 responden (40\%) responden, berat badan (BB) $54-57 \mathrm{~kg}$ sebanyak 15 responden (50\%). Berdasarkan kategori status gizi paling 
banyak terdistribusi pada kategori IMT normal sebanyak 27 responden (90\%), tingkat pendidikan tinggi (D3/ S1) sebanyak 24 responden (80\%) dan frekuensi senam aerobik tinggi sebanyak 15 reponden (50\%). Selanjutnya, analisis data dilanjutkan pada analisis bivariat yaitu melihat hubungan antara variabel bebas dan terikat. Hal ini terlihat pada Tabel 2.

Tabel 2. Hasil analisis bivariat

\begin{tabular}{cccccc}
\hline & Var. Terikat & \multicolumn{2}{c}{ Status gizi } & \multirow{2}{*}{ Total } & \multirow{2}{*}{ Nilai p } \\
Var. Bebas & & Normal & Tidak normal & & \\
\hline Tingkat & Tinggi & 22 & 2 & 24 & \multirow{2}{*}{0,501} \\
pendidikan & Menengah & 5 & 1 & 6 & \\
Frekuensi & Tinggi & 13 & 2 & 15 & \multirow{2}{*}{1,000} \\
senam aerobik & Rendah & 14 & 1 & 15 & \\
\hline Total & & 27 & 3 & 30 & \\
\hline
\end{tabular}

Tabel 2 menunjukkan hasil tabulasi silang yaitu responden dengan status gizi normal paling banyak terdistribusi pada tingkat pendidikan tinggi sebanyak 22 responden dan status gizi tidak normal pada pendidikan menengah sebanyak 1 responden. Hal ini menunjukkan bahwa secara tidak langsung menunjukkan bahwa semakin tinggi pendidikan maka status gizi semakin baik (normal). Selanjutnya data yang diperoleh ini selanjutnya diuji secara statisitika menggunakan uji Fisher's Exact. Hasil analisis statistik ini diperoleh nilai $\mathrm{p}=0,501(\mathrm{p}>0,05)$. Nilai $\mathrm{p}$ ini menunjukkan bahwa berdasarkan uji statistik diperoleh tingkat pendidikan berhubungan tidak signifikan dengan status gizi.

Hasil penelitian yang sejalan dengan Prayitno et al (2019) dan Niska et al (2017) yang menunjukkan bahwa tidak terdapat hubungan antara tingkat pendidikan dengan status gizi. Hal ini terjadi karena pendidikan tidak hanya didapatkan dari pendidikan formal tetapi juga didapatkan dari pendidikan nonformal. Selain itu, pendidikan tentang gizi hanya diperoleh pada sekolah atau lembaga pendidikan bidang kesehatan. Menurut United Nations International Children's Emergency Fund (UNICEF), akar masalah faktor penyebab gizi kurang adalah krisis ekonomi, politik dan sosial. Hal tersebut menyebabkan terjadinya berbagai masalah pokok dalam masyarakat, seperti: (a) pengangguran, inflasi, kurang pangan dan kemiskinan, (b) kurang pemberdayaan wanita dan keluarga, kurang pemanfaatan sumber daya masyarakat serta (c) kurang pendidikan, pengetahuan dan ketrampilan. Masalah-masalah pokok pada masyarakat menyebabkan 3 (tiga) hal sebagai penyebab tidak langsung kurang gizi, yaitu (1) tidak cukup persediaan pangan, (2) pola asuh anak tidak memadai, dan (3) sanitasi dan air bersih, pelayanan kesehatan dasar tidak memadai. Timbulnya ketiga masalah tersebut mengakibatkan makanan tidak seimbang serta menimbulkan penyakit infeksi sebagai penyebab langsung kurang gizi (Zaidi et al 2013). Hal ini bisa dilihat pada Gambar 1. 


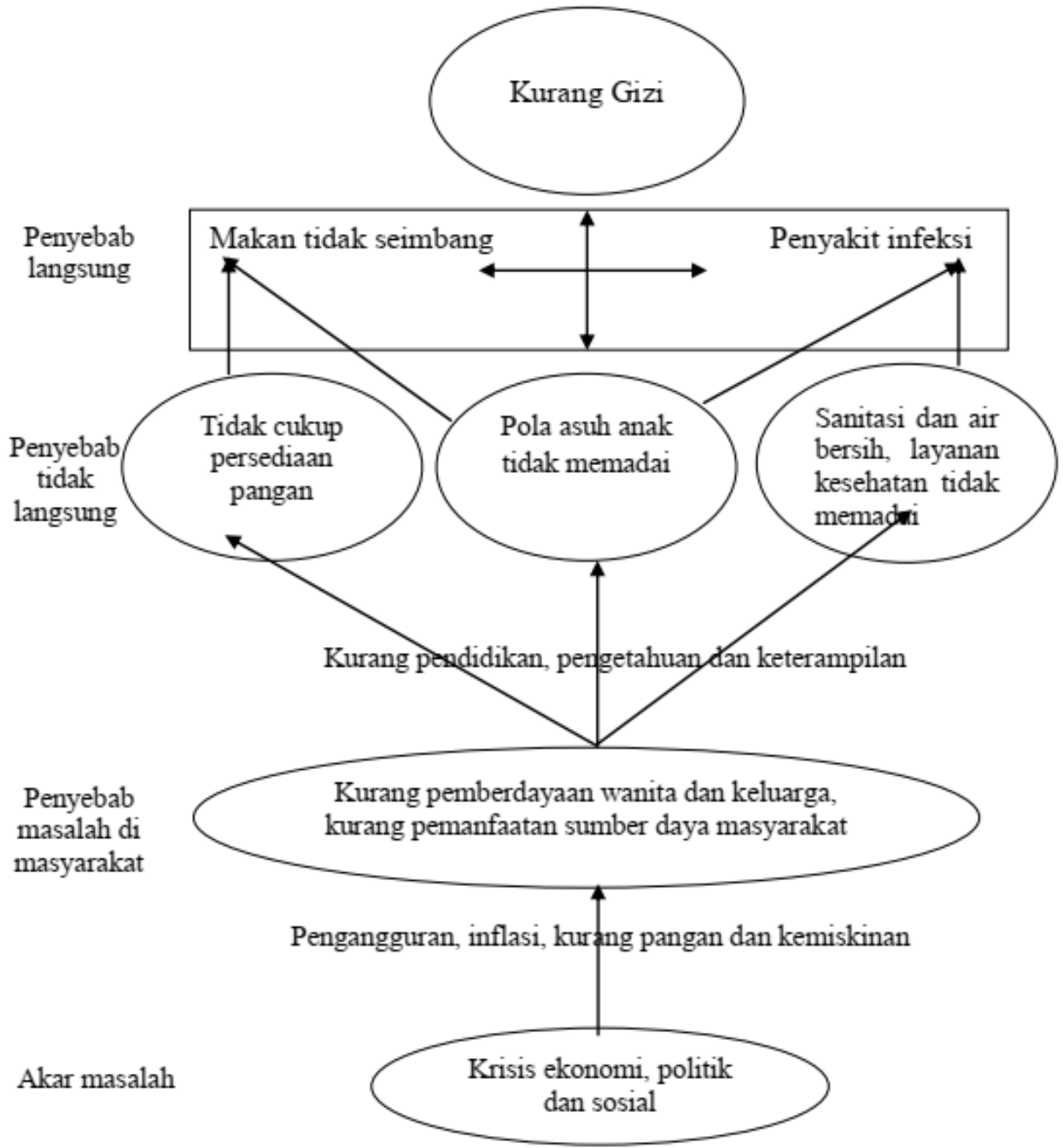

Gambar 1. Faktor penentu status gizi (Zaidi et al 2013)

Berdasarkan Gambar 1, terlihat bahwa pendidikan merupakan salah satu faktor penentu status gizi. Namun, pendidikan merupakan faktor yang tidak langsung menentukan status gizi sehingga menyebabkan beberapa hasil penelitian termasuk dalam penelitian ini menunjukkan bahwa tingkat pendidikan berhubungan tidak signifikan dengan status gizi.

Selanjutnya terlihat bahwa responden dengan status gizi normal paling banyak masuk pada kategori frekuensi senam aerobik rendah sebanyak 14 responden dan status gizi tidak normal paling banyak masuk pada kategori tinggi sebanyak 2 responden. Berdasarkan hasil tabulasi silang ini diperoleh bahwa frekuensi senam aerobik tidak menunjukkan kecenderungan berhubungan atau tidak dengan status gizi. Oleh karena itu dilanjutkan pada analisis statistika menggunakan uji Fisher's Exact. Berdasarkan analisis statistik ini diperoleh nilai $p=1,000(p>0,05)$. Nilai $p$ ini berarti frekuensi senam aerobik secara statistik berhubungan tidak signifikan dengan status gizi atau bisa dinyatakan bahwa frekuensi senam aerobik tidak berhubungan dengan status gizi.

Hasil penelitian sejalan dengan penelitian dari Kuswary dan Rachmanida (2018) yang menunjukkan tidak terdapat hubungan antara senam aerobik dengan status gizi. Penelitian dari Ayu et al (2017) tentang hubungan frekuensi senam aerobik dan asupan kolesterol terhadap kadar kolesterol darah wanita usia subur menunjukkan bahwa 
frekuensi senam aerobik tidak berhubungan dengan kadar kolesterol darah.

Namun beberapa penelitian sebelumnya menunjukkan hasil yang berbeda. Penelitian dari Kamal et al (2013) menunjukkan bahwa upaya penurunan berat badan dapat dilakukan latihan fisik dengan intensitas ringan dengan durasi 30 menit dan rutin dapat membakar lemak dalam tubuh sebesar 64,9 Kkal. Pembakaran lemak yang terjadi saat latihan fisik disebabkan akibat peningkatan metabolisme basal, peningkatan lipolisis, peningkatan massa otot serta peningkatan produksi panas sehingga menyebabkan pengeluaran keringat dan penurunan berat badan (Deliens et al., 2015). Durasi latihan fisik yang efektif dalam proses penurunan berat badan selama 30 menit/minggu dengan frekuensi 3 kali seminggu (Jakicic et al., 2011). Menurut Dewantari (2018) penerapan latihan fisik berupa senam aerobic dapat menurunkan berat badan. Latihan fisik berupa senam aerobic selama 3 - 5 kali seminggu dengan durasi waktu 20-30 menit dapat menurunkan berat badan secara signifikan. Hasil penelitian dari Ria (2017) menunjukkan adanya hubungan antara frekuensi senam aerobik dengan persentase lemak tubuh dan tidak terdapat hubungan antara intensitas senam aerobik dengan persentase lemak tubuh. Hasil penelitian dari Kuswari et al (2015) menunjukkan bahwa senam aerobik mempengaruhi perubahan lemak tubuh sehingga bisa merubah status gizi seseorang.

Perbedaan hasil penelitian ini disebabkan karena ada perbedaan karakteristik responden dan masih faktor-faktor lain yang berhubungan dengan status gizi namun tidak diteliti dalam penelitian ini. Menurut Suhardjo (2003) faktor-faktor yang memengaruhi status gizi yaitu (1) faktor pertanian yang meliputi seluruh usaha pertanian mulai dari penanaman sampai dengan produksi dan pemasaran; (2) faktor ekonomi, yaitu besarnya pendapatan keluarga yang digunakan untuk memenuhi kebutuhan pangan keluarga; (3) faktor sosial budaya meliputi kebiasaan makan, anggapan terhadap suatu makanan yang berkaitan dengan agama dan kepercayaan tertentu, kesukaan terhadap jenis makanan tertentu; (4) faktor fisiologi, yaitu metabolisme zat gizi dan pemanfaatannya oleh tubuh, keadaan kesehatan seseorang, adanya keadaan tertentu misalnya hamil dan menyusui; dan (5) faktor infeksi, yaitu adanya suatu penyakit infeksi dalam tubuh.

Menurut Soekirman, faktor penyebab kurang gizi atau yang mempengaruhi status gizi seseorang yaitu penyebab langsung dan penyebab tidak langsung. Penyebab langsung seperti asupan atau/ makanan dan penyakit infeksi yang mungkin diderita. Timbulnya gizi kurang tidak hanya karena makanan yang kurang, tetapi juga karena penyakit. Anak yang mendapatkan makanan cukup baik, tetapi sering diserang diare atau demam, akhirnya dapat menderita kurang gizi. Demikian juga makan tidak cukup baik, maka daya tahan tubuhnya akan melemah. Dalam keadaan demikian mudah diserang infeksi yang dapat mengurangi nafsu makan, dan akhirnya dapat menderita kurang gizi. Penyebab tidak langsung yaitu ketahanan pangan di keluarga, pola pengasuhan, serta pelayanan kesehatan dan kesehatan lingkungan (Sitorus et al, 2019; Bitty et al, 2019; Sumampouw 2019; Nurmidin et al, 2019).

\section{PENUTUP}

Kesimpulan dari penelitian ini yaitu tingkat pendidikan dan frekuensi senam aerobik tidak berhubungan dengan status gizi. Berdasarkan hasil penelitian ini maka dibutuhkan penelitian lanjutan tentang faktor lain yang berpengaruh pada status gizi seperti penyakit infeksi dan asupan makanan yang termasuk faktor yang langsung menentukan status gizi. 


\section{REFERENSI}

Ayu, A. M., Mutalazimah, M., \& Herawati, I. (2017). Hubungan Frekuensi Senam Aerobik dan Asupan Kolesterol terhadap Kadar Kolesterol Darah Wanita Usia Subur di Pusat Kebugaran Syariah Agung Fitnes Makamhaji. Jurnal kesehatan, 10(2), 74-82.

Bitty, F., Asrifuddin, A., \& Nelwan, J. E. (2019). Stres dengan Status Gizi Remaja di Sekolah Menengah Pertama Negeri 2 Manado. KESMAS, 7(5).

Deliens, T., Deforche, B., De Bourdeaudhuij, I., \& Clarys, P. (2015). Determinants of physical activity and sedentary behaviour in university students: a qualitative study using focus group discussions. BMC public health, 15(1), 1-9.

Harianti. 2018. Hubungan Pengetahuan, Tingkat Pendidikan, Pendapatan Keluarga Dengan Status Gizi Balita Di Wilayah Kerja Puskesmas Muara Uya Kabupaten Tabalong Kalimantan Selatan. Skripsi. Fakultas Ilmu Kesehatan, Program Studi Ilmu Gizi, Universitas Respati Yogyakarta

Hidayati, N. (2017) Hubungan Asupan Energi, Protein, Lemak, Karbohidrat Dengan Status Gizi Pada Santriwati Di Pondok Pesantren Darusalam Al-Faisholiyah Sampang Madura. Skripsi. Universitas Nahdatul Ulama Surabaya (online) diakses dari http://repository.unusa.ac.id/1740/ pada 19 Mei 2021

Irianto, P. 2017. Pedoman Gizi Lengkap Keluarga dan Olahragawan. CV. Andi Offset. Jogjakarta

Jakicic, J. M., Otto, A. D., Lang, W., Semler, L., Winters, C., Polzien, K., \& Mohr, K. I. (2011). The effect of physical activity on 18-month weight change in overweight adults. Obesity, 19(1), 100-109.

Kamal, M., Kusmana, D., Hardinsyah, H., Setiawan, B., \& Damanik, R. M. (2013). Pengaruh olahraga jalan cepat dan diet terhadap tekanan darah penderita prahipertensi pria. Kesmas: Jurnal Kesehatan Masyarakat Nasional (National Public Health Journal), 7(6), 279-283.

Kementerian Kesehatan RI. 2018. Riset Kesehatan Dasar. Jakarta

Kuswari, M., Setiawan, B., \& Rimbawan, R. (2015). Frekuensi Senam Aerobik Intensitas Sedang Berpengaruh Terhadap Lemak Tubuh Pada Mahasiswi Ipb. Jurnal Gizi dan Pangan, 10(1).

Kuswary, M., \& Rachmanida, N. (2018). Pengaruh Senam Aerobik Intensitas Sedang (Low Impact) Terhadap Komposisi Tubuh Mahasiswi Peserta Aerofun Universitas Esa Unggul (online) diakses dari http://www.litbang.kemkes.go.id:8080/handle/123456789/21646 pada 19 Mei 2021

Niska, N., Devriany, A., \& Fitrah, F. (2017). Hubungan Pendidikan dan Pekerjaan Ibu dengan Status Gizi Anak Pra Sekolah. Jurnal Kesehatan Poltekkes Kemenkes Ri Pangkalpinang, 5(2), 33-40.

Nurmidin, M. F., Fatimawali, F., \& Posangi, J. (2020). Pengaruh Pandemi Covid-19 Terhadap Aktivitas Fisik dan Penerapan Prinsip Gizi Seimbang Pada Mahasiswa Pascasarjana. Indonesian Journal of Public Health and Community Medicine, 1(4), 28-32.

Prayitno, F. F., Angraini, D. I., Himayani, R., \& Graharti, R. (2019). Hubungan Pendidikan dan Pengetahuan Gizi Dengan Status Gizi Ibu Hamil pada Keluarga dengan Pendapatan Rendah di Kota Bandar Lampung. Jurnal Medula, 8(2), 225229. 
Ria, H., Nur, H., \& Weni, K. (2017). Hubungan Antara Frekuensi Dan Intensitas Senam Aerobik Dengan Persentase Lemak Tubuh Pada Pesenam Aerobik Wanita (Doctoral dissertation, Poltekkes Kemenkes Yogyakarta).

Sitorus, C. E., Mayulu, N., \& Wantania, J. (2020). Hubungan Konsumsi Fast Food, Makanan/Minuman Manis dan Aktifitas Fisik Dengan Kadar Gula Darah Dan Status Gizi Mahasiswa Fakultas Kedokteran Universitas Sam Ratulangi. Indonesian Journal of Public Health and Community Medicine, 1(4), $10-17$.

Suhardjo. 2003. Pangan Gizi dan Pertanian. Universitas Indonesia. Jakarta

Sumampouw, O. J. (2020). Epidemiologi Demam Berdarah Dengue di Kabupaten Minahasa Sulawesi Utara. Sam Ratulangi Journal of Public Health, 1(1).

Supariasa dan Hardinsyah. 2016. Ilmu Gizi Teori dan Aplikasi. EGC. Jakarta.

Supariasa. 2013. Penilaian Status Gizi (Edisi Revisi). EGC. Jakarta.

Syafe'i, M. M. (2017). Seminar Kepelatihan Pelatih Senam Aerobik Sekabupaten Karawang. In Seminar Nasional Pengabdian kepada Masyarakat (Vol. 2, pp. 167-173).

Wati, S. P. (2019). Hubungan Tingkat Pendidikan, Pengetahuan Ibu dan Pendapatan Orangtua dengan Status Gizi Anak Balita Usia 1-5 tahun di Desa Duwet Kecamatan Wonosari Kabupaten Klaten (Doctoral dissertation, Universitas Muhammadiyah Surakarta).

World Health Organization. 2017. Obesity and Overweight (Online) diakses dari http://www.who.int/mediacenter/factsheets/fs311/en/ pada 7 Juli 2020.

Zaidi, S., Bhutta, Z. A., Mohmand, S. K., \& Acosta, A. M. (2013). The political economy of undernutrition national report: Pakistan. (online) diakses dari https://www.researchgate.net/publication/258857156_THE_POLITICAL_ECON OMY_OF_UNDERNUTRITION_NATIONAL_REPORT_PAKISTAN_March 2013 pada 20 Mei 2021 